\title{
Steven Saxonberg
}

ORCID: https://orcid.org/0000-0001-6057-2762 Comenius University, Faculty of Social and Economic Sciences, Institute of European Studies and International Relations Masaryk University, Department of Social Policy and Social Work ${ }^{1}$

Tomáš Sirovátka

ORCID: https://orcid.org/0000-0001-6891-2258 Masaryk University, Department of Social Policy and Social Work ${ }^{2}$

\section{Some thoughts about the interplay between welfare attitudes and populism ${ }^{3}$}

\begin{abstract}
This article argues for setting a research agenda to investigate more concretely the interplay between welfare attitudes and support for populist parties. It notes that although much has been written about populism, much less has been written about the interplay

1 Correspondence: Steven Saxonberg, Masaryk University, Institute of Public Policy and Social Work, Joštova 218/10, 60200 Brno, Czechia and Comenius University, Institute of European Studies and IR, Fakulta sociálnych a ekonomických vied UK, Mlynské luhy 4, 82105 Bratislava, Slovakia, author's email address: steven.saxonberg@fses.uniba.sk

2 Correspondence: Tomáš Sirovátka, Masaryk University, Institute of Public Policy and Social Work, Joštova 218/10, 60200 Brno, Czechia, author's email address: sirovatk@fss.muni.cz

3 Financing: Slovak Grant Agency: APVV-17-0596 "Politics of Emotions as a Form of Political Inclusion and Exclusion", Grant Agency of the Czech Republic:19-12289S for the project "Explaining the Support of New forms of Populism: the Czech Republic and Slovakia in a Comparative Perspective."
\end{abstract}


between populism and welfare attitudes. In addition, populism has tended to concentrate on rightwing populism while devoting less attention to leftwing populism. Meanwhile, centrist populist parties have been even more neglected than leftwing populism. We need to develop a more nuanced view and conduct comparative analyses of the differences in welfare attitudes among leftwing, centrist and rightwing populist voters. Our article also notes that the current databases that have both voting and welfare attitudes often do not include the countries with the most important leftwing populist parties. Another problem is the need to take into account the country context. For example, Podemos in Spain, Syriza in Greece and Smer in Slovakia are all three normally considered to be leftwing populist parties, but only Smer has promoted an anti-immigrant and anti-Roma agenda.

Key words: populism, welfare attitudes, political parties

If Marx were alive today, he might write something like "there's a specter haunting Europe and that specter is populism". In recent years populist parties have made great inroads throughout the democratic world. There has been a tendency to see populist movements as being "rigthwing" - such as Trump in the USA, the Freedom Party in Austria, the Swedish Democrats in Sweden, Berlusconi's various parties in Italy, and the National Front in France. Despite this tendency to emphasize the rightwing populist parties, recently leftwing populist parties have emerged. This includes Podemos in Spain and Syriza, which actually came to power for a few years in Greece. In the post-communist world rightwing populist parties rule in such countries as Hungary and Poland, but in Slovakia, Smer has dominated the political scene for the past decade. Although some might consider its anti-Roma and anti-immigrant stances to be typical of rightwing populist parties, it is a member of the socialist bloc in the EU parliament and it considers itself to be a social-democratic party. Similarly, the Czech President Miloš Zeman has clear populist tendencies. Similar to Smer he considers himself to be "social demoratic" and had even previously been prime minister as leader of the Czech social democratic party and similar to Smer he has run anti-immigrant campaigns. So even though the literature on populism has mostly focused on rightwing populism, it is necessary to also analyze leftwing populism and compare the differences and similarities between these types of populism.

Since populist parties have come to power in some countries and have become major opposition movements in others, we would expect them to have far-reaching influence on the political climate. Social policy researchers, such as Svallfors (1997) have claimed that in modern democracies, class struggles have moved from battles over ownership to battles over welfare policies (e.g. Esping-Andersen, 1990; Ginsburg, 1992; Svallfors, 1997) as an expression of the distributional (class) conflict (Korpi, 1980). If this is true, then we would expect populist movements to also influence welfare policies as well as attitudes toward welfare among the population. 


\section{What is a "Populist" Party}

If we are to discuss the interaction between welfare attitudes/policies and populist parties, first we need to define what we mean by "populism". It is common to label parties populist if they pose themselves as representatives of "the people" against the "elite" (e.g. Gidron \& Bonikowski, 2013). The people are virtuous and the source of the legitimacy for the populist parties (cf. Spruyt, Keppens \& Van Drrogenbroek, 2016, p. 336). Populism pits virtuous and homogenous people against elites and dangerous "others" (Pogunkte \& Scarrow, 1995) who are together "depicted as depriving (or attempting to deprive) the sovereign people of their rights, values, prosperity, identity and voice". Thus, like other exponents of populism, entrepreneurial populists take aim at unaccountable elites and pursue a catch-all strategy by offering popular but vague proposals on a number of salient policy issues.

Populist parties do not have a clearly-defined universal ideology, such as Marxism or liberalism. Instead they are bound by the cultural context of the political landscape in their country (Arter, 2010; Gidron and Bonikowski, 2013). Consequently, their ideas cut across traditional ideological cleavages (Kaltwasser, 2014). Because of this, populist politicians claim to support policies in line with the interest of median voter (Acemoglu et al., 2011, p. 31). Due to this "lack of key values" populism is "particularly liable to the politics of personality" (Taggart, 2000, p. 101, in Gidron and Bonikowski, 2013, p. 13). Although populism does not comprise an ideology in the traditional sense, it still aims for the "thin center" (Mudde, 2004; Freeden, 1996; Stanley, 2008).

Thus, even if populist parties only have a thin ideology, scholars often consider populism to be a specific discourse or ideology, where the key emphasis is on the tension between "the people" versus the elites, as well as between "the people" and the "dangerous others." For those on the left, these groups are large business corporations and financial interests. For those on the right these groups are minority groups like immigrants, environmentalists, and feminists. Populism combines centralized organizational structures with charismatic leaders and the understanding of democracy as unmediated popular sovereignty (Zaslove, 2008, p. 323).

Most of the literature focuses on the populist right, but populist movements cover the entire political spectrum. Zaslove (2008) distinguishes center, radical right, left and national populist parties. Mudde (2007) differentiates between radical rightwing populist parties (which oppose liberal democracy) and non-radical populist rightist parties (which accept liberal democracy). It is difficult sometimes to distinguish between radical and populist movements as they two groupings have a high degree of overlap. This is because the recent radical right and radical left parties usually no longer openly question liberal democracy and instead criticize the political establishment (Rooduijn \& Akkerman, 2017). For example, Le Front National was usually considered a radical right party, but under the tutelage of the founder's daughter, Marie Le Pen, the party has toned down its anti-system stance and is now usually considered more of a populist party with a thinner ideology than a radical right party, which had a thicker, neo-fascist ideology under Jean-Marie Le Pen. 
The rise of populism is often tied to globalization. Some scholars claim that globalization and the breakdown of the post-war social-market compromise between labor and capital is the source of the rise of populism. If this is true, then the performance of the welfare state and the assessment of the welfare state by the public is one of the key triggers of this change. Taggart (in Zaslove, 2008, p. 324), for example, claims that growing demand for welfare benefits, raised expectations to such levels that government could not adequately respond to voters in an era in which governments felt forced to cutback government spending in order to lower taxes and therefore, compete on the global market for capital investments.

\section{What is a "leftist" or "rightist" Party}

If it is true that populists often have rather vague, "thin" ideologies and try to become "catch-all" parties that promise everything to everyone (at least to everyone belonging to the "in-group"), then it becomes difficult to decide whether a populist party is a leftwing or rightwing populist party. Even names are not clear. For example, to the extent that one might consider the Nazis to have been a populist party, their name included the words "socialist" and "workers' party," yet they are usually classified as being rightwing extremists rather than leftists. Since they actually had a thick ideology based on race biology, they are normally not considered to be populist but rather extremist. However, other parties that are usually considered to be rightwing populist parties often tend to have rather generous social policies, which make them somewhat "leftist". This is true of both the Law and Justice party (PiS) in Poland and FIDESZ in Hungary. In both countries, the communist parties reformed themselves after the fall of communism and repackaged themselves as "socialist" parties. They joined the Socialist International and the socialist bloc in the EU parliament. Yet, while in power they often enacted radical free-market reforms including "liberal" kinds of residual social policies based on targeting and meanstesting. Meanwhile, the rightwing populist parties in both countries have introduced or sometimes reintroduced - much more generous welfare schemes that sometimes are also universal in nature (such as child allowances in Poland). Since universalism is usually associated with social democratic welfare policies and residualist means-testing with liberal welfare states, it becomes difficult to label these populist parties as being rightwing or leftwing.

Another problem in determining whether a party is leftwing or rightwing is the issue of how one should judge them. Should social scientists base it on what parties say - for example, by analyzing their election manifestos - or should they base it on what the parties actually do? There can be great differences as once in government one faces pressures to adapt policies to what other organizations (such as international creditors, business organizations, etc.) demand. As Syriza in Greece found out, even though they won the election on a leftwing, anti-austerity manifesto and even though they also won a referendum against the austerity measures that the EU wanted to impose on them, when 
faced with the choice of leaving the Eurozone and perhaps even the EU, they balked and introduced the austerity measures that the EU demanded. Does that make them a rightwing populist because they changed their policies?

In our opinion the best way to solve the issue of whether a populist party is left, center or right is to base it on self-placement. For example, even though one could argue that Smer in Slovakia supports traditional rightwing populist parties (such as being anti-Roma, anti-immigrant, nationalist, basically against universal and generous welfare programs), it considers itself to be social democratic, it joined the socialist international and is a member of the socialist bloc in the EU parliament. Thus, we would consider it to be a leftwing populist party, because that is how it packages itself. Then as social scientists, we can ask the question as to why a populist party claiming to be "leftist" advocates policies in Slovakia that are so radically different from what leftwing populist parties advocate in such countries as Germany, Greece and Spain. We can also analyze whether these selfproclaimed leftist parties really support the types of policies that social scientists claim are typical of leftwing populist parties. In itself, it is an interesting outcome as to how self-identification differs from the attempts of social scientists to develop "objective" criteria for determining whether a populist party is leftist or rightist (or even centrist).

\section{Right-wing populism and the welfare state}

The main discourse on rightwing populism has concerned the issue of welfare chauvinism (e.g. De Koster et al., 2013; Emmenegger \& Klemmensen, 2013; Van der Waal et al., 2010; Van Oorschot, 2000, 2006). According to this notion, supporters of rightwing populist parties consider immigrants to be "unworthy" of receiving welfare benefits. Those, who fare poorly because of globalization, tend to perceive immigrants and minority ethnic groups to be competitors. Their fears of competition for scarce resources increase when immigration increases (e.g. Lubbers et al., 2002; Arzheimer \& Carter, 2006). Rightwing populists play on this fear of competition and portray the ethnic majority as being good citizens, while immigrants and ethnic minorities are "undeserving" because they are "lazy." They claim that these outsiders abuse the system to gain welfare benefits to which they are not entitled (e.g. Swank and Betz, 2003; Burgoon et al., 2018).

Some studies, however, conclude that univeralist, social democratic welfare states depress the support for welfare chauvinism despite the increasing insecurity that globalization has brought about (Swank \& Betz, 2003; Reeskens \& Van Oorschot, 2013). The logic is that universalist welfare states encourage inclusiveness as everyone benefits from the policies. Consequently, it is common to think that everyone - regardless of background - has the right to benefit from social welfare programs. Means-tested politics, by contrast, emphasize the issue of deservingness, as targeted programs are supposed to only target the "deserving". Thus, those paying taxes but not receiving benefits might doubt whether those receiving benefits really deserve it. Moreover, whether true or not, in countries with liberal welfare states, where most benefits are targeted, the boulevard 
media portray immigrants or ethnic minorities as people, who abuse the welfare state. Another explanation is that social democratic welfare states reduce poverty and social inequality, which makes deservingness less of an issue.

The question is whether such arguments about welfare states still hold up, since rightwing populist parties have gain in support in recent years in the Nordic countries with social democratic welfare states. It the last elections in Sweden, the rightwing populist, anti-immigrant party the Swedish Democrats came in third place, receiving over $17 \%$ of the votes (Valmyndigheten, 2018). Meanwhile, in Finland the rightwing populist Finns Party also received over $17 \%$ of the votes (Statistics Finland, 2019) and just missed being the largest party in parliament by $25 \%$. Meanwhile, in Denmark the rightwing populist Danish People's Party also came in second place in the 2015 elections, but with $21.1 \%$ of the votes they were even more popular than their Finnish counterpart (Wikipedia, 2019). In the 2019 elections this populist party dropped dramatically to $8.7 \%$ of the votes, but the fact that it had done so well in the previous election still casts doubt on the argument that social democratic welfare states prevent the rise of rightwing populist parties. However, it does seem likely that they have helped prevent the rise of leftwing populist parties, as none of the Nordic countries have large leftwing populist parties in parliament.

Other studies report that rightwing populist voters do not view ethnic minorities as less deserving per se, but rather they oppose giving more benefits to these groups because they allegedly display "unfavorable" characteristics (Koostra, 2016). Ennser-Jedenastik (2018) suggests that social insurance and universal social benefits (based on citizenship) lead to low levels of welfare chauvinism, while a high level of chauvinism arises for programs based on residency or means-testing. His findings confirm that the contribution-based elements of social programs are less likely to draw nativist criticism (for a similar conclusion see also Reeskens \& Van Oorschot, 2013). This would still lead to the conclusion that social democratic and Christian Democratic/conservative welfare states dampen support for rightwing populism, since most benefits are based on contributions. Yet, as noted above, in recent years rightwing populist parties have done well in the Nordic, social democratic countries. They have obviously done also quite well in countries with conservative welfare systems, such as France, Germany and Austria.

Other studies have concluded that economic conditions and immigration have influenced support for rightwing populism. The traditional argument was that increased inflation and unemployment during the 1970s and 1980s contributed to the mobilization of latent right-wing extremist attitudes among the public — especially among those who lost out during the modernization processes (e.g. Betz, 1994, Kitschelt \& McGann, 1995) and those who for any reason became unemployed (Jackman \& Volpert, 1996). On the other hand, other studies provide contradictory results: unemployment does not exert the anticipated effect on potential vote support for rightwing populist parties. On the contrary, increasing unemployment actually decreases support for rightwing populist parties (Knigge, 1998; Lubbers et al., 2002; Arzheimer and Carter, 2006). The explanation is that when unemployment is on rise, traditional left-wing parties as well as mainstream 
center and center-right wing parties develop policies for dealing with these issues, so voters turn to these parties rather than small oppositional populist parties (Knigge, 1998; Arzheimer and Carter, 2006). Furthermore, people in wealthy countries are afraid to lose what they have gained in times of prosperity (Lubbers et al., 2002), so they do not want to risk their gains by voting for populist parties, whose policies might threaten their economic well-being. New kinds of parties represent a risk if they have not yet been in power and it is difficult to gage what the results of their policies would be.

On the other hand, Golder (2003) claims that the level of immigration and unemployment influence support for rightwing populist parties, although these issues do not influence support for radical, extremist rightwing parties (such as fascist ones). However, the effect of unemployment of this support depends on the level of immigration: when the immigration rate is high, increasing unemployment leads to greater support for rightwing populist parties. Thus, Rygdren and Ruth (2013) find that in Sweden higher unemployment rates and lower average incomes lead to greater support for rightwing populism, because the socio-economically marginalized come into potential conflict with immigrants over scarce resources. This shows that socioeconomic issues can influence support for rightwing populism in social democratic countries as well as in liberal and conservative ones.

\section{Left-wing populism and the welfare state}

Even though most of the literature has dealt with rightwing populism, leftwing populist parties are also on the rise. In Latin America, leftwing populist parties have been more prominent than in Europe; consequently, there have been more studies about the Latin American cases. For example, Rodrik (2018) claims that while rightwing populism in Europe is based on the fear that immigrants will erode welfare benefits, in Latin America, leftwing populism is based on the fear of austerity programs. In these countries, they fear that international organizations such as the IMF will impose austerity programs enforcing welfare cutbacks, while pressuring governments to allow foreign companies to take over utilities and national resources. Although he acknowledges the existence of leftist populism, he sees it as mostly a Latin American phenomenon rather than something that has impact on European politics.

Nevertheless, some recent studies have analyzed the rise of radical left-wing populism in Europe. These studies conclude that leftwing populist parties embrace state intervention in the economy, they claim to have socialist or social democratic principles, but also tend to oppose the EU's austerity policies and engage in some amount of economic nationalism. They oppose a "neo-liberal Europe" but not a "social Europe" (e.g. Rooduijn et al., 2017). As Kriesi (2014, p. 370) notes, rather than emphasize the nation, leftwing populists tend to emphasize defense of the national welfare state against Europe and they want to defend "the economic privileges of domestic sectors of the economy and of domestic production sites". Or as March (2007, p. 66) puts it: 
Left-populists are "populist" in that the "moral people versus corrupt elite" dichotomy is central to their ideology. They generally have far less concern with doctrinal purity and class-consciousness than the traditional left. They adopt organizational features common to other populist parties across the political spectrum, such as the emphasis on a charismatic leader who has unmediated communication with his people and distaste for formal organization. Nevertheless, they are "left" in their emphasis on egalitarianism, and their identification of economic inequity as the basis of existing political and social arrangements. The espousal of collective economic and social rights for their chosen people constitutes their principal agenda.

Similarly, March and Mudde (2005, p. 35) write about what they see as the emergence of leftwing populist parties, which accept parliamentary democracy and have an anticapitalist profile:

However, whereas traditional socialists' egalitarianism and 'proletarian' anti-elitism might seem to lend themselves towards populism, their concern with doctrinal principle and the correct class politics did not. The social-populist parties are less overtly Marxist, and as concerned with extending their vote as constituency representation. They are populist in terms of juxtaposing "the moral people" against "the corrupt elite."

Thus, similar to the rightwing populist parties, their ideology is "thin" and they support the "people" against the "elite." Yet, in contrast to rightwing populists, they emphasize defending the national welfare state and egalitarianism. Similar to the rightwing populists, though, they oppose globalization. In the recent developments of welfare states, the window of opportunity for left-wing populism increased because social democratic parties have often supported welfare state retrenchment. Leftwing populist parties emerge when there is no credible left, as the left has been associated with communism (in Slovakia) or where the main socialist or social democratic parties become known for corruption and their market-oriented policies differ little from the rightwing parties (Greece and Spain). The voters of these parties hold leftwing views on social policies, but are disenchanted with the political elite. This leads to the hypothesis that supporters of leftwing populist parties will be more supportive than supporters of rightwing populist parties of general welfare policies. In particular they support government redistribution, redressing the privileges of the rich elite and the idea of social justice (Burgoon et al., 2018, March, 2011; Ramiro, 2016; Rooduijn et al., 2017; Visser et al., 2014).

When it comes to the country-level economic aspects, some studies have concluded that worsening economic conditions and high levels of income inequality increase support for the leftwing populism parties. The empirical evidence, however, is not convincing. While some studies confirm expectations a about positive correlation of unemployment and support for rightwing populist parties (March and Rommerskirchen, 2015), others provide different results. Visser et al. (2014) find that unemployment and GDP level is not associated with support for "social populists," and income inequality is negatively correlated with support for such populist groups. The reason is that in the absence of a strong radical left, concerns about income inequality are less prominent in public debates, so less support for leftwing populism emerges. In addition, the degree of social 
mobility might be more important than income inequality in explaining support for leftwing populism.

In contrast, Rooduijn and Burgoon (2018) document that immigration figures matter in interaction with individual economic hardship for voting for the radical left (including those parties classified as being "populist"): individual economic hardship only leads to radical left voting if the immigration level is low. Risk avoidance can explain this: since radical left parties are not very interested in immigration, the less well-off may perceive it to be risky to vote for the radical left when immigration rate is high, because they are afraid that immigrants will "steal" their jobs and welfare provisions. What is interesting in this context is that in Slovakia, the leftwing populist party Smer has played the anti-immigrant card even though the country has very few immigrants. In addition, our preliminary calculations that we have done for Slovakia show that there is no correlation at all between anti-immigrant attitudes and voting for Smer. In other words, it seems that Smer has run an anti-immigrant campaign despite the fact that there are not many immigrants so little reason exists to be concerned about this issue, and they have continued this campaign despite the fact that it does not seem to have gained them any votes. Yet, at the same time Smer had been the dominant party in Slovak politics during this decade, having been in power since 2012 (either in coalitions or by itself). Similarly, in the Czech Republic, the leftwing populist, Miloš Zeman, has been president since 2013, having been reelected in 2018. Even though he had previously been the head of the Czech Social Democratic Party and even had been prime minister as a representative of that party, he eventually left this party to found a new populist-leftist party that has consistently failed to reach parliament. Nevertheless, Zeman remains popular and won his reelection on an openly anti-immigrant campaign.

\section{Center Populist Parties and Welfare Attitudes}

If it is not always clear what makes a populist party "leftist" or "rightist" then the category of "centrist populist party" becomes even more vague. However, there are a large number of parties, which experts have classified as being "populist," which are neither clearly leftist or rightist. Just to take one example, Rooduijn et al. (2019) compiled a wellknown database on populist parties. They list of no less than 8 parties in Bulgaria alone, which existed from 2001-2014, which are indeed populist but neither leftist or rightist.

It is not clear whether all the populist parties that are neither clearly leftist or rightist should be considered centrist and it is not clear whether centrist populist parties have anything in common with each other. Their particular stances on welfare issues probably depends on the political situation of their specific country; however, the same can probably be said about leftwing and righting populist parties. To give the example, ANO in the Czech Republic has emerged as the largest party with a clear centrist profile. We would argue that they did not emerge as the largest party because there was a demand for a populist party, but rather they emerged as the largest party because there was a demand for a social liberal party. Survey data indicates that the vast majority of Czechs have 
social liberal attitudes (e.g. Saxonberg, 2003; Saxonberg \& Sirovatka, 2009) in that they want a generous welfare state, but they do not trust the state to carry out policies and deliver services. Therefore, in contrast to social democracy, they prefer a system with cash benefits and private services.

Contrary to what is often assumed, supply (i.e. political parties) do not always arise in order to meet demand (i.e. the wishes of the voters). Instead, what seems to have happened in the Czech case is that many centrist voters have voted for parties, whom they perceived to be a centrist alternative to the dominating center-right party Civic Democratic Forum (ODS). Thus, in the 1992 and 1996 elections they voted for the Civic Democratic Alliance (ODA); however, it turned out that even though the party was largely comprised of intellectual former dissidents, their actual policies in practice were even more free-market oriented than ODS, so after two elections, they disappeared from parliament. Then in 1997 the Freedom Union (US) broke away from ODS. Similar to ODA they were largely comprised of intellectual former dissidents and similar to ODA the voters perceived them as being to the left of ODS, but similar to ODA, their actual policies were even more market-oriented than ODS. So once again after two periods in parliament the party collapsed. Once this happened, a third party with a similar background emerged, TOP09, which was founded in 2009 under the leadership of the aristocrat Karel Schwarzenberg, who had served as foreign minister as an independent having been proposed by the Green Party. Similar to ODA and US the party had an image of being to the left of ODS and therefore, many social liberal voters flocked to the party. In the 2010 elections it received over $16 \%$ of the vote, becoming the third largest party and it formed a coalition government with ODS. Another party leader, Miroslav Kalousek (formerly of the Christian Democrats) became finance minister and carried out policies that were more market-liberal than those of previous ODS governments, despite the total lack of support for such policies among its voters (e.g. Saxonberg \& Sirovatka, 2014). When voters started noticing that the party was actually to the right of ODS on economic issues, it began losing support, falling to $12 \%$ in the 2013 elections. In contrast to ODA and US, it has survived a third election and remains in parliament, but it has lost $2 / 3$ of its original voters, receiving a mere $5.3 \%$ in the 2017 elections (https://www.volby.cz/).

It is in this situation in which the majority of voters have social liberal values, but neo-liberal, free market values dominate among the political elite, made it possible for ANO as a catch-all populist party to emerge. It fulfilled the social liberal ambitions of the electorate by promising more generous benefits; yet, in typical catch-all, populist fashion, it also promised to do so without increasing taxes. Survey data shows that its voters do seem to share social liberal values, as they want generous welfare policies but do not consider themselves to be "leftists." In contrast to rightwing populist voters, they are not skeptical of the EU, neither are they anti-immigrant. Their voters also come from typical social liberal backgrounds in that they tend to be highly educated and from the middle class (Heinisch \& Saxonberg, 2017). So, it seems that it was the absence of a social liberal alternative on the supply side that made it possible for ANO to ascend to power, first as a junior coalition partner in 2013 and then as the major coalition leader in 2017. 
Further Studies

Ideally, we would want to use the available international databases to conduct multilevel-multinomial analyses of who votes for different types of populist parties. The European Social Survey from 2016 presents the most recent international survey that includes many questions about welfare attitudes as well as questions about voting. Unfortunately, both Greece and Slovakia are missing from this survey, which means that the two countries, where leftwing populist parties have been in power are excluded. Given the fact that the number of countries in the survey with leftwing populist parties is rather limited and the two largest leftwing populist parties (Syriza and Smer) are missing, there are not enough cases to be able to make certain conclusions about what factors influence voting for leftwing parties. As often is the case in the social sciences, we have to do the best we can with our imperfect data.

A second problem is that as noted, it is not so clear whether we really can group the different types of populist parties together. The country context seems to matter a lot. For example, Smer considers itself to be a leftwing, social democratic party, yet it shares a lot of common traits with traditional rightwing populist parties, such as its antiimmigrant and anti-Roma stances. This differs greatly from the other most important leftwing populist parties, such as Podemos in Spain, Die Linke in Germany and Syriza in Greece. In addition, although ANO captures the social-liberal voters in the Czech Republic, it is not clear whether this is the case in other countries. Rooduijn et al. (2019) label Berlusconi's parties as being neither left nor right. We would differ and label it as a rightwing populist party. In any case, if one would accept their classification, it would make Forza Italia a "centrist" populist party, but it is doubtful whether its voters share the same social liberal values as in the Czech case. Because no two countries are the same and no two political parties are the same, we need to simplify and use these wide kinds of classifications. However, since we clearly miss some important nuances, we should complement with country case studies.

\section{References}

Acemoglu, D., Egorov, G., \& Sonin, K. (2011). A Political Theory of Populism, NBER Working Papers 17306, National Bureau of Economic Research, Inc.

Arter, D. (2010). The Breakthrough of Another West European Populist Radical Right

Party? The Case of the True Finns. Government and Opposition, 45(4), 484-504.

Arzheimer, K. (2009). Contextual factors and the extreme right vote in Western Europe, 1980-2002. American Journal of Political Science, 53(2), 259-275.

Arzheimer, K., \& Carter, E. (2006). Political opportunity structures and right wing extremist party success. European Journal of Political Research, 45(3), 419-443.

Betz, H. G. (1994). Radical right-wing populism in Western Europe. MacMillan Press LTD. 
Burgoon, B., van Noort, S., Rooduijn, M., \& Underhill, G. R. D. (2018). Radical right populism and the role of positional deprivation and inequality. LIS Working Paper Series, No. 733. https://www.econstor.eu/bitstream/10419/203019/1/1026676711.pdf

De Koster, W., Achterberg, P., \& Van Der Waal, J. (2013). The New Right and the Welfare State: the Electoral Relevance of Welfare Chauvinism and Welfare Populism in the Netherlands. International Political Science Review, 34(1), 3-20.

Emmenegger, P., \& Klemmensen, R. (2013). Immigration and Redistribution Revisited: How different Motivations Can Offset Each Other. Journal of European Social Policy, 23(4), 406-422.

Ennser-Jedenastik, L. (2018). Welfare Chauvinism in Populist Radical Right Platforms: The Role of Redistributive Justice Principles, Social Policy \& Administration, 52(1), 293-314.

Esping-Andersen, G. (1990). The Three Worlds of Welfare Capitalism. Polity Press.

Freeden, M. (1996). Ideologies and Political Theory: A Conceptual Approach. Oxford University Press.

Gidron, N., \& Bonikowski, B. (2013). Varieties of Populism: Literature Review and Research Agenda. In Weatherhead Working Paper Series, No. 13-0004.

Ginsburg, N. (1992). Divisions of Welfare: A Critical Introduction to Comparative Social Policy. Sage.

Golder, M. (2003). Explaining variation in the success of extreme right parties in Western Europe. Comparative Political Studies, 36(4), 432-466.

Heinisch, R., \& Saxonberg, S. (2017). Entrepreneurial Populism and the Radical Centre: Examples from Austria and the Czech Republic. In R. C. Heinisch, C. Holtz-Bacha, O. Mazzoleni (eds.), Political Populism: A Handbook. (209-226). Nomos.

Jackman, R. W., \& Volpert, K. (1996). Conditions favouring parties of the extreme right in Western Europe. British Journal of Political Science, 26(4), 501-521.

Kaltwasser, C. R. (2014). The Responses of Populist to Dahl's Democratic Dilemmas, Political Studies, 62, 470-487.

Kitschelt, H., \& McGann A. J. (1995). The Radical Right in Western Europe. University of Michigan Press.

Knigge, P. (1998). The ecological correlates of right-wing extremism in Western Europe. European Journal of Political Research, 34(2), 249-279.

Kootstra, A. (2016). Deserving and Undeserving Welfare Claimants in Britain and the Netherlands: Examining the Role of Ethnicity and Migration Status Using a Vignette Experiment. European Sociological Review, 32(3), 325-338.

Korpi, W. (1980). Social Policy and Distributional Conflict in the Capitalist Democracies: A Preliminary Comparative Framework. European Politics, 3, 296-316.

Kriesi, H. K. (2014). The Populist Challenge, West European Politics, 37(2), 361-378.

Lubbers, M., Gijsberts, M., \& Scheepers, P. (2002). Extreme right-wing voting in Western Europe. European Journal of Political Research, 41(3), 345-378. 
March, L. (2007). From vanguard of the Proletariat to Vox Populi: Left-populism as a 〈Shadow〉 of Contemporary Socialism, Sais Review of International Affairs, 27(1), 63-77.

March, L. (2011). Radical Left Parties in Europe. Routledge.

March, L., \& Mudde, C. (2005). What's Left of the Radical Left? The European Radical Left after 1989: Decline and Mutation. Comparative European Politics, 3(1), $23-49$.

March, L., \& Rommerskirchen, Ch. (2015). Out of left field? Explaining the variable electoral success of European radical left parties, Party Politics, 21(1), 40-53. https:// doi.org/10.1177/1354068812462929

Mudde, C. (2004). The Populist Zeitgeist. Government and Opposition, 39(4), 542-563.

Mudde, C. (2007) Populist Radical Right Parties in Europe. Cambridge University Press.

Pogunkte, T., \& Scarrow, S.E. (1995). The politics of anti-party sentiment. European Journal of Political Research, 29(3), 257-262.

Ramiro, L. (2016). Support for radical left parties in Western Europe: social background, ideology and political orientations. European Political Science Review, 8(1), 1-23.

Reeskens, T., \& Van Oorschot, W. J. H. (2013). Equity, equality, or need? A study of popular preferences for welfare redistribution principles across 24 European countries, Journal of European Public Policy, 20(8), 1174-1195.

Rodrik, D. (2018). Populism and the Economics of Globalization, Journal of International Business Policy. https://doi.org/10.1057/s42214-018-0001-4

Rooduijn, M., \& Akkerman, T. (2017). Flank attacks: Populism and left-right radicalism in Western Europe. Party Politics, 23(3), 193-204.

Rooduijn, M., Burgoon, B., van Elsas, E. J., \& van de Werfhorst, H. G. (2017). Radical distinction: Support for radical left and radical right parties in Europe. European Union Politics, 18(4), 536-559.

Rooduijn, M., \& Burgoon, B. M. (2018). The paradox of wellbeing: Do unfavorable socioeconomic and sociocultural contexts deepen or dampen radical left and right voting among the less well-off? Comparative Political Studies, 51(13), 1720-1753.

Rooduijn, M., Van Kessel, S., Froio, C., Pirro, A., De Lange, S., Halikiopoulou, D., Lewis, P., Mudde, C., \& Taggart, P. (2019). The PopuList: An Overview of Populist, Far Right, Far Left and Eurosceptic Parties in Europe. http://www.popu-list.org.

Rydgren, J., \& Ruth, P. (2013). Contextual explanations of radical right-wing support in Sweden: Socioeconomic marginalization, group threat, and the halo effect. Ethnic and Racial Studies, 36(4), 711-728.

Saxonberg, S. (2003). The Czech Republic Before the New Millennium. East European Monographs, Columbia University Press.

Saxonberg, S., \& Sirovatka, T. (2009). Czech Family Policy: Refamilialization in the Face of Contradictory Public Attitudes. Journal of Societal and Social Policy, 7(3).

Saxonberg, S., \& Sirovatka, T. (2014). From A Garbage Can to a Compost Model of Decision-Making? Social Policy Reform and The Czech Government's Reaction to the International Financial Crisis, Social Policy and Administration, 48(4), 450-467. 
Spruyt, B., Keppens G., \& Van Droogenbroeck F. (2016). Who Supports Populism and What Attracts People to It? Political Research Quarterly, 69(2), 335-346.

Stanley, B. (2008). The Thin Ideology of Populism. Journal of Political Ideologies, 13(1), 95-110.

Statistics Finland (2019). Parliamentary elections 2019, result of the control calculation. http://www.stat.fi/til/evaa/2019/evaa_2019_2019-04-24_tie_001_en.html

Svallfors, S. (1997). Worlds of Welfare and Attitudes to Redistribution: A Comparison of Eight Western Nations. European Sociological Review, 13(3), 283-304.

Swank, D., \& Betz, H. G. (2003). Globalization, the welfare state and right-wing populism in Western Europe. Socio-Economic Review, 1(2), 215-245.

Taggart, P. (2000). Populism. Open University Press.

Valmyndigheten (2018). Val till riksdagen - Röster. https://data.val.se/val/val2018/slutresultat/R/rike/index.html

Van Der Waal J., Achterberg P., Houtman D. et al. (2010). 'Some Are More Equal than Others': Economic Egalitarianism and Welfare Chauvinism in the Netherlands. Journal of European Social Policy, 20(4): 350-363.

Van Oorschot, W. (2000). Who Should Get What, and Why? On Deservingness Criteria and the Conditionality of Solidarity among the Public. Policy \& Politics, 28(1), 33-48.

Van Oorschot, W. (2006). Making the Difference in Social Europe: Deservingness Perceptions among Citizens of European Welfare States. Journal of European Social Policy, 16(1), 23-42.

Visser, M., Lubbers, M., Kraaykamp, G., \& Jaspers, E. (2014). Support for radical left ideologies in Europe. European Journal of Political Research, 53(3), 541-558.

Wikipedia (2019). 2019 Danish general election. https://en.wikipedia.org/wiki/2019_Danish_ general_election

Zaslove, A. (2008). Here to Stay? Populism as a New Party Type. European Review, 16(3), 319-336. 